\title{
İş İlanlarının Çekiciliği: Mesaj Belirginliğinin Etkisi
}

\author{
Attractiveness of Recruitment Advertisements: Impact of Information Specificity
}

Esra ALNIAÇIK ${ }^{1}$

\begin{abstract}
ÖZET
İ̧̧ ilanları, işletmelerin yetenekli çalışanları kendilerine çekmek için kullandıkları önemli araçlardan birisidir. iş ilanlarının temel amacı, işletmenin ihtiyaç duyduğu niteliklere sahip çalışanlara iş ile ilgili bilgi vermek ve onların işletmeye iş başvurusu yapmalarını sağlamaktır. $\mathrm{Bu}$ araştırmada, adayların iş ilanlarına başvuru yapma niyeti üzerinde etkisi olan bazı değişkenler incelenmiştir. Bu çerçevede, iş ilanı içinde işletmenin çalışanlara sunduğu olanaklarla ilgili bilgiyi verip vermemenin ve de bu bilgiyi genel bir ifadeyle ya da ayrıntılı bir şekilde vermenin, adayların iş ilanına yönelik tutumlarını ve ilanda belirtilen pozisyona başvuru yapma niyetini nasıl etkilediği irdelenmiştir. Bu amaçla, kurgusal iş ilanları hazırlanarak üniversite öğrencileri üzerinde bir deneysel araştırma gerçekleştirilmiştir. Araştırma sonucunda, iş ilanlarında kurumun çalışanlara sunduğu olanaklara ilişkin bilgi vermenin, adayların iş başvurusu yapma niyetini olumlu yönde etkilediği; bu bilginin genel bir ifade yerine ayrıntılı bir şekilde verilmesinin daha da olumlu bir etki yaptığı belirlenmiştir. Buna ilaveten, son sınıflarda okuyan mezuniyet aşamasındaki öğrencilerin ayrıntılı bir şekilde sunulan bilgiden, alt sınıflardaki öğrencilere nazaran daha fazla etkilendiği de ortaya çıkarılmıştır. Sonuçlar üzerinde tartışılarak, uygulamacılara ve araştırmacılara çeşitli öneriler sunulmuştur.
\end{abstract}

Anahtar Kelimeler: İş İlanı, Başvuru Niyeti, İş Illanına Yönelik Tutum, Mesaj Belirginliği, Örgütsel Çekicilik

\section{GíRiş}

Günümüzde işletmeler için sürdürülebilir rekabet avantajının en önemli kaynağı yetenekli çalışanlardır. Örgütün amaçlarına ulaşabilmesi için, insan kaynaklarının etkili ve verimli bir şekilde yönetilmesi gerekmektedir. Yetenekli çalışanların işletmeye çekilmesi, en doğru adayların işe alınması ve çalışanlar ile işletme arasında karşılıkı tatmini sağlayacak uzun süreli ilişkilerin kurulması insan kaynaklarıyönetiminin öncelikli görevleri arasındadır. İnsan kaynakları yönetiminin en temel işlevlerinden birisi olan işe alım süreci hem işletmeler, hem de çalışanlar için oldukça hassas bir süreçtir. Bu süreçte aday kendisi için en uygun işi bulmaya çalışırken, işletme de oluşturacağı havuz içinden açık olan pozisyona en uygun adayı

\begin{abstract}
Job advertisements are important tools used by companies to attract talented employees. Main functions of job ads are informing potential employees about job posts and convincing them to apply for the job. This study investigates some variables that may affect the attractiveness of job ads. Particularly, the study examines the effects of the specificity of information given in a job advertisement on the potential applicants' willingness to apply for the job opening and their attitudes toward the job ad. Results of an experimental study on 600 undergraduate students revealed that, providing information about the benefits offered by the job increased the likelihood to apply for the job. Further, specific and concrete messages found to generate a higher level of intention to apply for the job, when compared to vague and general messages. Finally, results indicated that students in their final year of study were more sensitive to specific messages when compared to other students. These findings are discussed in detail and theoretical and managerial implications are provided.
\end{abstract}

Keywords: Job Advertisement, Willingness to Apply, Attitude towards Job Ad, Message Specificity, Organisational Attractiveness

seçmek amacındadır. Aday açısından bu süreç, adayın çalışmayı arzuladığı iş ve işletme hakkında aldığı bir dizi karar olarak tanımlanan iş seçim sürecidir. İşe alım ve iş seçim süreçlerinde, her iki tarafın birbiriyle ilk teması ve iletişimi için kullanılan araçlardan belki de en önemlisi iş ilanlarıdır.

Iş ilanları, bir işletmenin açık olan pozisyonları hakkında hedef kitleleri bilgilendirmek ve uygun nitelikteki adaylardan oluşan geniş bir aday havuzu oluşturmak amacıyla, belirli bir ücret karşılığında gazetelerde, dergilerde, internette ya da diğer mecralarda yayınlanan duyurulardır. İşe alma süreci bir yönetsel uygulama olduğu kadar bir pazarlama aracı olarak da görülmektedir (Kaplan, Aamodt, ve Wilk 1991; Maurer, Howe, ve Lee 1992). Bu bağlamda, işe 
alım sürecinde kullanılan iş ilanları, pazarlamacıların kullandıkları mal ve hizmet reklamları gibi ikna edici iletişim araçlarıdır (Allen, Van Scotter ve Otondo, 2004; Ryan vd. 2000). İş ilanları sadece açık olan pozisyonları duyurmakla kalmamakta; bir işveren markası yaratma, adayları bu kurumun doğru işveren olduğu konusunda ikna etme gibi işlevleri de yerine getirmektedir (Neely-Martinez, 2002). İş ilanların temel işlevleri adayların dikkatini çekmek, ilan edilen işe yönelik ilgi uyandırmak, istek oluşturmak ve nihayetinde de iş başvurusu yapma yönünde eyleme geçirmektir (Belt ve Paollilo, 1982). Adayların bir işe başvuru yapmadan önce o işle ilgili bilgi aldığı ilk mecra çoğu kez işletmeler tarafından yayınlanan bu iş ilanları olmaktadır. Iş ilanları bir taraftan, açık olan pozisyon için nitelikli adaylardan oluşan geniş bir havuz oluşturmaya hizmet ederken, diğer taraftan da istenen özeliklere sahip olmayan adayların en baştan elimine edilmesini de sağlamaktadır (Gatewood ve Field, 1998). Bu nedenle iş ilanlarının doğru ve gerçekçi şekilde hazırlanması ve yayınlanması işe alım süreci için son derece önemlidir. İş ilanlarının hangi formatta hazırlanacağı (yazılı, resimli, sesli, görüntülü vb.), ilanda hangi bilgilere yer verileceği (işletmenin kendisi, adaylarda aranan özellikler, işin tanımı, çalışanlara sunulan olanaklar vb.) mesajın nasıl oluşturulacağı gibi pek çok konuda doğru kararlar verilmesi gerekmektedir.

Uluslararası literatürde işe alım süreci ve iş ilanları üzerine son otuz yıl içinde giderek artan sayıda araştırma yapıldığı görülmektedir (Lee vd. 2013; Walker vd. 2008; Feldman vd., 2006; Blackman, 2006; Thorsteinson ve Highhouse 2003; Breaugh, 2005; Roberson vd., 2005; Reeve ve Schultz, 2004; Breaugh ve Starke, 2000; Fernandes ve Rosen, 2000; Highhouse vd., 1999; Rafaeli ve Oliver, 1998; Yüce ve Highhouse, 1998; Turban vd. 1998; Turban ve Greening, 1996; Goltz ve Gianantonio 1995; Barber ve Roehling, 1993; Gatewood vd., 1993; Kaplan vd., 1991; Mason ve Belt, 1986; Powell, 1984; Belt ve Paolillo, 1982; Fisher vd., 1979). Bu araştırmaların çoğu ABD kaynaklıdır ve özellikle Afrika ve Orta Doğu ülkelerinde önemli bir literatür eksikliği vardır (Abernety ve Franke, 1996). Mevcut çalışmalar arasında iş ilanlarının içeriğini inceleyen araştırmaların sayısı azdır (Van Hoye ve Lievens, 2005). Buna ilaveten, Türkiye'de konu ile ilgili literatür birkaç çalışma ile sınırlıdır (Erdem ve Gezen, 2014; Acarlar ve Bilgiç, 2013; Baş, vd., 2011) ve bu alanda önemli bir eksiklik vardır. Bu eksikliği belirli ölçüde gidermek amacıyla üniversite öğrencileri üzerinde deneysel bir araştırma yapılmıştır. Bu araştırmada, işgücü pazarının önemli kaynakları olan üniversite öğrencilerinin, bir ilandaki işe başvurma niyetlerinin ve ilana yönelik tutumlarının ilandaki mesaj içeriğinden nasıl etkilendiği incelenmiştir. Bu araştırmanın, konu ile ilgili literatüre katkı yapmasının yanında daha etkili iş ilanları hazırlama konusunda uygulamacılara da faydalı ipuçları sunması beklenmektedir. Bu çerçevede, öncelikle araştırma konusu ile ilgili bir literatür özeti sunulmuştur. Literatür özetinden sonra araştırmanın yöntemi açıklanmıştır. Daha sonra verilerin analizi ve bulgular ortaya konmuş, en son bölümde ise tartışma ve önerilere yer verilmiştir.

\section{LITERATÜR ÖZETI ve HIPOTEZLER}

İşletmelerin, rekabet avantajı sağlayacakyetenekli çalışanları kendilerine çekmeleri için, işe alım sürecinin her aşamasında en doğru kararları vermeleri gerekir. İşe alım sürecinde işletmeler açısından temel hedef, intiyaç duydukları çalışanları seçebilecekleri geniş ve nitelikli aday havuzları oluşturmak ve buradan en doğru seçimleri yapmaktır. İş ilanları, potansiyel çalışanların açık pozisyonlardan haberdar olmaları ve iş başvurusu yapmak üzere işletmeye çekilmelerini sağlayacak temel araçlardan biridir. İyi hazırlanmış iş ilanları sayesinde kurumlar, aradıkları özelliklere sahip adayların iş başvurusu yapmalarını temin ederken, istenen özelliklere sahip olmayan adayları da en baştan eleyerek zaman ve kaynak tasarrufu sağlayabilirler. Bu nedenle, günümüzün yetenek savaşlarında iyi hazırlanmış iş ilanları işletmeler için çok önemli bir araç haline gelmiştir.

Adaylar açısından bakıldığında, bu aşamadaki temel amaç, işin gerçekçi bir ön tanıtımına dayalı olarak kendisi için en uygun işe ve işletmeye yerleşebilmektir. İşin gerçekçi öntanıtımı (realistic job preview), çalışanların işten ayrılma niyetini azaltarak ve daha uzun süre işletmede çalışmaya devam etmelerini sağlayarak, hem çalışan hem de işletme açısından verimliliği artırmaktadır (Wanous, 1978). Iş ilanları, potansiyel çalışanlar için işgücü pazarındaki iş fırsatları ve bu fırsatları sunan işletmeler hakkında bilgi veren önemli sinyal kaynaklarıdır (Rynes 1991; Turban ve Greening 1996) ve çalışan adaylarının işletme ile ilk temas noktaları olarak, onlara kurumun hangi pozisyonlar için ne tür çalışanlar aradığı ve seçim sürecinin nasıl oluşacağı konusunda temel bilgileri verir (Dowling 1988). İş arama sürecinin başında, potansiyel çalışanlar iş başvurusu yapabilecekleri 
işletmeler hakkında iş ilanlarından öğrendikleri dışında çok az bilgiye sahiptirler. İşletme ve ilan edilen iş hakkında sınırlı bilgiye sahip olan adaylar, ellerindeki bu bilgilere dayalı olarak bazı çıkarımlar yapabilirler. $\mathrm{Bu}$ da onların kurum hakkındaki ilk algılamalarını şekillendirebilir. Dolayısıyla iş ilanlarında verilen bilgiler kadar verilmeyen bilgiler de adayları etkileyebilir.

İş ilanlarının istenen etkiyi yaratma kapasiteleri üzerinde pek çok faktörün etkisi bulunmaktadır. Bu faktörleri ilanın yayınlandığı mecra (gazete, dergi, internet vb.) ilanın estetik unsurları (boyut, renk, grafik tasarım, sayfadaki yerleşimi, kullanılan görseller vb.) ve ilandaki mesajın içeriği (verilen bilgi miktarı, mesaj çerçevesi, kaynak, tek-çift yönlü mesaj kullanımı vb.) şeklinde üç ana başlıkta incelemek mümkündür. İş ilanındaki mesaj içeriği, ilanı yayınlayan işletmelerin adaylara aktarmak istediği temel bilgileri taşır ve ikna açısından en önemli faktördür. Adaylar iş ilanındaki mesajın içeriğini genellikle şu dört ana başlıkta değerlendirirler: kuruma ilişkin bilgiler, işin tanımı ve içeriği, adaylarda aranan özellikler ve çalışanlara sunulan olanaklar (Belt ve Paolillo 1982). Bu unsurların her biri adayların iş ilanına vereceği tepkiyi dramatik bir şekilde etkileme kapasitesine sahiptir. Örneğin, Rynes ve Miller (1983) ilanda işin tanımı ve özelliklerine ilişkin bilgi vermenin iş arayanların algıladıkları firma çekiciliğini anlamlı bir şekilde etkilediğini ortaya koymuştur, Diğer taraftan, Belt ve Paolillo (1982) adaylarda aranan özelliklere ilişkin verilen bilginin ayrıntı derecesinin adayların iş ilanına verdikleri tepki üzerine anlamlı bir etkisi olmadığını belirlemiştir. Mason ve Belt (1986) ise, adaylarda aranan özelliklere ilişkin ayrıntılı bilginin, nitelikleri ilandaki işe uygun olmayan adaylar üzerinde negatif bir etki yaptığını ortaya koymuştur. Bir iş ilanının başarısı üzerinde etkisi olan bu kadar fazla faktörün hepsini birden aynı anda incelemek oldukça zordur. Bu nedenle, mevcut araştırmada iş ilanında çalışanlara sunulan olanaklara ilişkin bilgilerin adayların iş ilanına verdikleri tepkiyi nasıl etkilediği incelenmiş, diğer faktörler araştırma kapsamı dışında tutulmuştur.

İş ilanlarında çalışanlara sunulan olanaklara ilişkin bilginin veriliş şeklinin, adayların iş başvurusu yapma niyeti üzerinde nasıl bir etkisi olduğuna ilişkin uluslararası literatürde çeşitli çalışmalar yer almaktadır. Örneğin, Roehling (2002), bir iş ilanına başvuru yapıp yapmama kararı üzerinde etkisi olan en önemli unsurların ilanda lokasyon ve maaş ile diğer ödemelere ilişkin bilgiler olduğunu belirlemiştir.
Başka araştırmalarda, eğitim, gelişim ve yükselme olanakları, maaş ve diğer yan ödemelere ilişkin bilgilerin bir iş ilanına başvuru yapma niyeti üzerinde anlamlı etkisi olduğu ortaya konmuştur (Powell, 1984; Taylor ve Bergmann, 1987). Kimi araştırmacılar da iş ilanında genel ve yüzeysel bilgiler yerine daha ayrıntılı bilgi sunmanın adayların başvuru niyetleri üzerinde daha olumlu etkisi olduğunu ileri sürmektedir (Allen vd., 2004; Roberson, Collins ve Oreg, 2005; Yüce ve Highhouse, 1998; Barber ve Roehling, 1993; Breaugh ve Billings, 1988; Mason ve Belt, 1986). İş ilanında gerek işin içeriği, gerekse çalışanlara sunulan olanaklarla ilgili verilen bilgi miktarı adayların ilanı veren kurumun itibarı ile ilgili algılamalarını olumlu yönde etkileyebileceği gibi, işe alma sürecinin olumlu şekilde sonuçlanması olasılığını da artırır (Feldman vd., 2006).

Reklamcılık literatüründe de, reklam mesajının belirgin ve ayrıntılı olması halinde reklamın daha etkili olacağı yönünde bilgiler bulunmaktadır. David Ogilvy (1983), reklamdaki belirgin ve ayrıntılı mesajların, genel ve yüzeysel iddialara göre daha inandırıcı ve daha çok akılda kalıcı olduğunu ileri sürmüştür. Reklam mesajının belirginlik düzeyinin azalması ise, reklamın inandırıcılığını azaltarak reklama yönelik negatif tutumlar ortaya çıkarmaktadır (Snyder, 1989). Daha sağlam mesajlar içeren reklamların daha dikkat çekici olduğu belirlenmiştir (MacKenzie, 1986). Aaker ve Stayman (1990) ise reklamın bilgilendiriciliğinin, reklamın beğenilirliği ve reklamdaki markaya yönelik tutuma ilişkin en güçlü tahminci olduğunu ortaya koymuştur. İş ilanları da bir çeşit reklam olarak kabul edildiğinden, benzer değerlendirmeler iş ilanları için de yapılabilir.

Bir iş ilanındaki bilgi miktarı ile adayların iş başvurusu yapma kararı arasında pozitif ilişki olduğu belirlenmiştir (Barber ve Roehling 1993; Gatewood, Gowan ve Lautenschlager, 1993). Daha fazla bilgi içeren iş ilanları, bu bilgi ilan edilen işle çok fazla alakalı olmasa bile, daha çekici olarak değerlendirilmektedir (Yüce ve Highhouse, 1998). Diğer taraftan, iş ilanında kimi bilgilere yer verilmemesi, adaylar tarafından ilgisizlik ve dikkatsizlik olarak yorumlanabilmektedir (Yüce ve Highhouse, 1998). Adayların, iş ilanında ayrıntılı bilgi verilen özelliklere (örneğin başlangıçta ödenecek maaş vb.), muğlâk ve belirsiz ifadelerle anlatılan özelliklerden daha fazla dikkat ettikleri de belirlenmiş̧tir (Barber ve Roehling, 1993).

Iş ilanlarında mesaj belirginliğinin, ilandaki işin adaya ne derece uygun olduğu konusundaki 
algılamaları, iş ilanın inandırıcılığını, iş ilanına ve ilanı veren işletmeye yönelik tutumu pozitif yönde etkilediği ortaya konmuştur (Feldman vd. 2006). Ayrıntılı bilgi içeren iş ilanının aday-örgüt uyumu konusunda daha olumlu algılamalara yol açtığı belirlenmiştir (Roberson vd., 2005). Algılanan adayörgüt uyumunun ise iş ilanındaki mesaj belirginliği ile iş başvurusu yapma niyeti arasındaki ilişkide ılımlaştırıcı etkisinin olduğu ortaya konmuştur. Iş̧ ilanında verilen bilginin miktarının yanında, içeriği de önemlidir. Eğer ilanda verilen bilgi işin kendisi ya da ilanı veren kurumla alakalı ise, ilan daha olumlu değerlendirilmektedir (Yüce ve Highhouse 1998). İş ilanındaki bilginin kalitesi ilanı veren işletmenin çekiciliğini ve iş başvurusu yapma niyetini etkilemektedir (Walker, Feild, Giles ve Bernerth, 2008). Bir başka çalışmada, iş ilanında adayların seçim sürecinde kullanılacak yöntemlere ilişkin bilgiye yer verip vermemenin de örgütsel çekicilik ve iş başvurusu yapma niyeti üzerinde etkisi olduğu; seçim sürecinde kullanılacak yöntemleri uygun bulan adayların, ilandaki işe başvuru yapma niyetlerinin daha yüksek olduğu belirlenmiştir (Reeve ve Schultz, 2004).

Diğer taraftan, iş ilanında ayrıntılı bilgiler verilmesi halinde, kimi adayların istenen özelliklere sahip olmadıklarını düşünmeleri, kimilerinin de ilanda belirtilen işi kendilerine uygun bulmamaları nedeniyle başvuru yapmaktan vazgeçmelerine bağlı olarak aday havuzunun daralması sonucu da ortaya çıkabilmektedir (Premack and Wanous 1986; Schneider, Smith, and Goldstein 2000).

Uluslararası literatüre genel olarak bakıldığında, iş ilanlarında ayrıntılı bilgiye yer vermenin adayların ilandaki işe ve ilgili işletmeye yönelik tutumlarını olumlu yönde etkilediği değerlendirilmektedir. Ülkemizde ise bu konudaki çalışma sayısı yok denecek kadar azdır. Acarlar ve Bilgiç (2013) tarafından ODTÜ öğrencileri üzerinde yapılan çalışmada iş ilanındaki bilgi miktarı ve bilginin inandırıcılığının örgütsel çekicilik ve iş başvurusu yapma niyeti üzerinde anlamlı etkisinin olduğu belirlenmiştir. Baş ve arkadaşları (2011) tarafından yapılan geniş kapsamlı bir başka araştırmada, üniversite öğrencilerinin işveren tercihinde öncelikle kariyer olanakları, çalışma şartları, görsel kimlik, ürün/hizmetler, örgüt kültürü ve rekabetçi konum faktörlerini dikkate aldıkları belirlenmiştir. Her ne kadar doğrudan iş ilanları üzerinde yapılmış olmasa da, bu çalışma iş ilanlarında yer verilmesi gereken bilgiler hakkında bir öngörü sunmaktadır.

Konu ile ilgili ulusal literatürdeki eksikliğe cevap vermek üzere yapılan bu araştırmada ise, iş ilanlarında adaylara sunulan olanaklara ilişkin verilen bilginin ayrıntı derecesinin, adayların iş ilanına yönelik tutumlarını ve ilandaki işe başvuru yapma niyetlerini nasıl etkilediği incelenmiştir. Yukarıda sunulan literatür özetine dayalı olarak, iş ilanı içinde işletmenin çalışanlara sunduğu olanaklarla ilgili bilgiye yer vermenin ve bu bilgiyi genel bir ifade yerine ayrıntılı bir şekilde sunmanın, adayların iş ilanına yönelik tutumlarını ve ilanda belirtilen pozisyona başvuru yapma niyetini daha olumlu yönde etkileyeceği öngörülmektedir. Bunun çeşitli gerekçeleri mevcuttur. Her şeyden önce, adaylar gerçekçi iş arama sürecinde kendi ilgi alanlarına, bilgi, beceri ve deneyim düzeylerine uygun pozisyonları araştııırlar. Bir pozisyonun kendilerine uygun olup olmadığını değerlendirmek için de ayrıntılı bilgiye intiyaç duyarlar. Adaylar, iş arama sürecinde ilan edilen pozisyonlar için görev tanımı, maaş ve yapılacak diğer ödemeler, eğitim ve yükselme olanakları, iş çevresi gibi bilgileri değerlendirirler (Cable vd. 2000; Cable ve Graham 2000). Yeterince bilgi içermeyen genel başvuru ilanlarındaki pozisyonların kendilerine uygun olmadığını düşünebilirler. Diğer taraftan adaylar, ayrıntılı bilgiler içeren iş ilanlarını daha ciddi olarak algılayabilir ve belirtilen özelliklere sahip adaylara daha iyi olanaklar sunulacağını düşünebilirler. Bunun arkasında yatan neden ise, genel iş başvurusuna yönelikilanlar yayınlayan işletmelerin, hâlihazırda açık bir pozisyon yokken özgeçmiş toplayarak kendilerine bir aday havuzu oluşturmayı amaçladıkları şeklinde bir algılama olabilir (Capelli 2001; Feldman ve Klaas 2002). Bu nedenle adaylar, genel başvuru ilanlarını gerçekçi ve bilgilendirici olarak görmeyebilirler (Feldman vd., 2006). Bu doğrultuda aşağıdaki hipotezler oluşturulmuştur.

Hipotez 1a: Sunulan olanaklar hakkında bilgi içeren iş ilanları, bu bilgiyi içermeyen ilanlara göre daha olumlu değerlendirilir.

Hipotez 1b: Sunulan olanaklar hakkında bilgi içeren iş ilanlarına başvuru yapma niyeti, bu bilgiyi içermeyen ilanlara başvuru yapma niyetinden daha yüksektir.

Hipotez 2a: Sunulan olanaklar hakkında ayrıntılı bilgiler içeren iş ilanları, bu konuda yüzeysel ve muğlâk bilgiler içeren ilanlara göre daha olumlu değerlendirilir.

Hipotez 2b: Sunulan olanaklar hakkında ayrıntılı bilgiler içeren iş ilanlarına başvuru yapma niyeti, bu 
konuda yüzeysel ve muğlâk bilgiler içeren ilanlara başvuru yapma niyetine göre daha yüksektir.

Diğer taraftan bireylerin, iş arama konusundaki ilgilenim ve motivasyon düzeyine bağlı olarak, ilandaki bilgi miktarına verdikleri tepkiler değişebilir. Örneğin, fiilen iş arama sürecinde olan ya da çok kısa süre sonra aktif iş arama sürecine dahil olacak olan üniversite son sınıf öğrencileri, daha alt sınıflarda okuyan ve henüz aktif iş arama sürecinde olmayan öğrencilere göre ayrıntılı bilgi sunan mesajlardan daha fazla etkilenebilirler. Bu bağlamda aşağıdaki hipotezler oluşturulmuştur.

Hipotez 3a: Illanda çalışanlara sunulan özellikler bilgisinin belirginlik düzeyinin artması, son sınıf öğrencilerinin ilana yönelik tutumunu, diğer öğrencilere göre daha fazla etkiler.

Hipotez 3b: Ilanda çalışanlara sunulan özellikler bilgisinin belirginlik düzeyinin artması, son sınıf öğrencilerinin ilandaki işe başvuru yapma niyetini, diğer öğrencilere göre daha fazla etkiler.

$\mathrm{Bu}$ hipotezlerin test edilmesi için üniversite öğrencileri üzerinde deneysel bir araştırma gerçekleştirilmiştir. Bir sonraki bölümde söz konusu araştırmanın yöntemi ayrıntılı bir şekilde açıklanmıştır.

\section{YÖNTEM}

Araştırmanın hipotezlerinin test edilmesi için bir deneysel tasarım hazırlanmıştır. Önce bir pilot çalışma yapılarak, ilanda kullanılacak sektör ve pozisyon belirlenmiştir. Deneysel tasarımda ise, pilot çalışmayla belirlenen sektör ve pozisyon için farklı içeriklerde hipotetik iş ilanları oluşturulmuştur. Farklı iş ilanlarını gören cevaplayıcıların iş ilanına yönelik tutumları ve ilandaki işe başvuru yapma niyetleri ölçülerek karşılaştırılmıştır.

\section{Pilot Çalışma}

Deneysel tasarımda kullanılacak hipotetik iş ilanlarında hangi sektörde hangi iş pozisyonunun kullanılacağına karar vermek için bir pilot çalışma yapılmıştır. Pilot çalışmada, üniversite öğrencileri arasından kolayda örnekleme yöntemiyle seçilen 300 kişiye, 55 işkolunu içeren geniş bir liste sunulmuş ve mezun olduklarında öncelikle çalışmak istedikleri sektörü bu listeden seçmeleri istenmiştir. Pilot çalışmada ve ana çalışmada bilgi toplanan cevaplayıcılar Kocaeli Üniversitesi, İktisadi ve İdari Bilimler Fakültesi (IIBBF) ile İletişim
Fakültesi öğrencilerinden oluşmaktadır. Pilot çalışma sonucunda öğrencilerin en çok çalışmak istedikleri ilk beş sektörün sırasıyla bankacılık ve finans, insan kaynakları yönetimi, pazarlama ve satış, muhasebe, halkla ilişkiler olduğu belirlenmiştir. Bu sektörler arasından, işgücü piyasasında en sık ilana çıkan ve gerek IIBBF gerekse İletişim Fakültesi öğrencilerine uygun olan bankacılık ve finans sektörü ana çalışma için seçilmiştir. Belirlenen sektör için gazetelerde ve kariyer sitelerinde yayınlanan güncel iş ilanları incelenmiş ve üniversiteden yeni mezun bireyler için başlangıç seviyesinde en yaygın pozisyonun müşteri temsilcisi pozisyonu olduğuna karar verilmiştir.

\section{Deneysel Tasarım}

Araştırmanın hipotezlerinin test edilmesi için denekler arası bir deneysel tasarım hazırlanmıştır. Pilot çalışmada belirlenen pozisyon için hipotetik bir iş ilanı oluşturulmuş, ilanın içeriği değiştirilerek üç farklı versiyon türetilmiştir. Araştırmaya katılan cevaplayıcılar, gazete ve dergilerde yayınlanmak üzere hazırlanmış bu üç farklı iş ilanı versiyonundan birini görecek şekilde rastgele gruplara atanmışlardır.

Oluşturulan iş ilanında, tanınmış bir kuruma yönelik mevcut tutumların herhangi bir yanlılık yaratmaması için kurum adına yer verilmemiş, bunun yerine iş ilanı bir kariyer danışmanlık şirketi tarafından yayınlanmış gibi hazırlanmıştır. İlanın başlık kısmında, aracılık yapan danışmanlık şirketinin adı, logosu ve açık olan pozisyonun adına yer verilmiştir. Başlık kısmının hemen altına "Danışmanlığını yapmakta olduğumuz Türkiye'nin önde gelen bankalarından birinde görev alacak 'Müşteri Temsilcileri' arıyoruz" ifadesi yerleştirilmiştir. Bu cümleden sonra sırasıyla adaylarda aranan özellikler, işin tanımı, sunulan olanaklar ve pozisyon hakkındaki diğer bilgiler (şehir, tecrübe, alınacak personel sayısı, pozisyonun tipi vs.) sunulmuştur. İlanın son kısmında ise ilgilenen adayların başvuru yapabilecekleri eposta adresi ve faks numarası verilmiştir. Bu ilanın içindeki "sunulan olanaklar" kısmındaki bilgiler değiştirilerek üç farklı versiyon hazırlanmıştır. İlk versiyonda, sunulan olanaklar bilgisine hiç yer verilmemiştir. Íkinci versiyonda, sunulan olanaklara ilişkin ayrıntılı olmayan genel ve muğlâk bilgiler verilmiştir (Tatmin edici maaş, Yükselme olanakları, Yüksek verimlilik primi ve hedef ödülleri, Eğitim ve kariyer geliştirme fırsatları, Sosyal destekler). Üçüncü versiyonda ise sunulan olanaklara ilişkin detaylı, somut ve belirgin bilgiler verilmiştir (bkz. EK-1). Üçüncü versiyonda 
başlangıç için çalışanlara ödenecek aylık ücret bilgisi de açık olarak verilmiştir. Burada verilen başlangıç maaşı, yeni mezunlar için cazip ancak fazla abartılı algılanmayacak makul bir düzeyde belirlenmiştir. İlanın şekli, kenarlığı, büyüklüğü, rengi ve maniple edilen kısım dışındaki diğer bilgileri her üç versiyonda da birebir aynıdır. Bu nedenle, ilanda çalışanlara sunulan olanaklara ilişkin bilgi üzerinde yapılan maniplasyonun, cevaplayıcıların iş ilanına verecekleri tepkilerdeki olası farklııkların nedeni olacağı düşünülmektedir.

\section{Veri Toplama Aracı}

Veriler çevrimiçi bir anket formu yardımıyla toplanmıştır. Üç sayfadan oluşan bu anket formunun ilk sayfasında kısa bir açıklamanın altında cevaplayıcıların demografik özelliklerine ilişkin sorular yer almaktadır. İkinci sayfada, cevaplayıcılara rastgele gösterilecek örnek iş ilanları bulunmaktadır. Cevaplayıcılara, görecekleri ilanın gerçek ve güncel bir iş ilanı olduğu söylenmiştir. Özel bir kurgu ile, her bir cevaplayıcıya hazırlanan iş ilanlarının rastgele bir versiyonunun gösterilmesi sağlanmıştır. Katılımcılar, üç farklı versiyonda hazırlanan bu iş ilanın rastgele kendilerine gösterilen bir versiyonunu inceledikten sonra, bir sonraki sayfaya geçmişler ve bu sayfada iş ilanına yönelik tutumları ve bu ilanda belirtilen işe başvurma niyetlerine yönelik soruları cevaplamışladır. İş ilanına yönelik tutumu ölçmek için Feldman vd.,(2006)'dan uyarlanan beş soruluk, 9 aralıklı (en olumsuz 0; en olumlu 8 olacak şekilde) bir anlamsal farklııı ölçeği kullanılmıştır. İlandaki işe başvurma niyetini ölçmek için ise Feldman vd.,(2006)'dan uyarlanan yedi soruluk Likert tipi beş aralıklı (1= Hiç katılmıyorum, 5= Tamamen Katılıyorum şeklinde) bir ölçek kullanılmıştır. Son bölümde ise, manipülasyon kontrolüne yönelik sorular yer almaktadır. Manipülasyon kontrolü için iş ilanının ne derece bilgilendirici olduğuyla ilgili beş soruluk Likert tipi beş aralıkı ı (1= Hiç katılmıyorum, 5= Tamamen Katılıyorum şeklinde) bir ölçek kullanılmıştır.

\section{Örneklem}

Araştırmaya kolayda örnekleme yöntemiyle seçilen 600 üniversite öğrencisi katılmıştır. Kocaeli Üniversitesi'nin IIIBF ve İletişim Fakültelerindeki lisans bölümlerinde okuyan bu öğrencilerin 174 tanesi mezuniyet durumundaki son sınıf öğrencileri, geriye kalanlar ise 2. ve 3. sınıfta okuyan öğrencilerdir.
Öğrencilerbuaraştırmayagönüllüolarakkatılmışlardır. Cevaplayıcıların \%53,7'si bayandır; yaşları 19-35 arasında değişmektedir ve yaş ortalaması 21,6'dır. Tamamına yakını (\%97) bekârdır. Cevaplayıcıların ailelerinin aylık ortalama gelirleri $2500 \mathrm{TL}$ civarındadır. Cevaplayıcıların \%66'sı daha önce herhangi bir yerde, staj dahil olmak üzere ücret karşılığında en az 1 ay çalıştıklarını; \%13'ü ise hâlihazırda bir işyerinde ücret karşılığında çalışmakta olduklarını belirtmişlerdir. Cevaplayıcılar her bir deney grubunda 200 kişi olacak şekilde rastgele atanmışlardır.

\section{ANALIZLER}

\section{Ölçeklerin Değerlendirilmesi}

Hipotez testlerinden önce, iş ilanına yönelik tutum, iş başvurusu yapma niyeti ve iş ilanının bilgilendiriciliği ölçeklerinin faktör yapısı ve güvenilirlikleri değerlendirilmiştir. Toplam 17 soru için yapılan keşifsel faktör analizinde, sorular beklendiği gibi üç faktöre yüklenmiştir.

Tablo 1'de görüldüğü gibi, beş sorunun yüklendiği ilk faktör, iş ilanına yönelik tutum olarak adlandırılmıştır. Bu faktör toplam varyansın $\% 25,07$ 'sini açılamaktadır. Yedi sorunun yüklendiği ikinci faktör, iş başvurusu yapma niyeti olarak adlandırılmıştır. Bu faktör toplam varyansın \%29,3'ünü açıklamaktadır. Beş sorunun yüklendiği son faktör ise, ilanın bilgilendiriciliği olarak adlandırılmıştır. Bu faktör toplam varyansın \%16,3'ünü açıklamaktadır. Ölçeklerin güvenilirliklerini değerlendirmek için Cronbach Alpha katsayıları hesaplanmıştır. İş ilanına yönelik tutum ölçeğinin güvenilirlik katsayısı 0,94; iş başvurusu yapma niyeti ölçeğinin güvenilirlik katsayısı 0,92 ve iş ilanının bilgilendiriciliği ölçeğinin güvenilirlik katsayısı da 0,80 olarak hesaplanmıştır. Bu sonuçlardan hareketle, bu üç ayrı ölçekteki sorular kendi içinde birleştirilmiş ve verilen cevapların aritmetik ortalamaları alınarak üç yeni kompozit değişken oluşturulmuştur. Oluşturulan bu iki kompozit değişken arasında orta kuvvette pozitif ve anlamlı bir korelasyon olduğu belirlenmiştir ( $r=, 351$ $p<0,001)$. Bu değişkenler bir sonraki aşamada hipotez testlerinde kullanılmıştır. 
Tablo 1: Kullanılan Ölçeklere İlişkin Faktör ve Güvenilirlik Analizi Sonuçları

\begin{tabular}{|c|c|c|c|c|c|c|}
\hline & $\begin{array}{l}\text { Art. } \\
\text { Ort. }\end{array}$ & $\begin{array}{l}\text { Std. } \\
\text { Sap. }\end{array}$ & $\begin{array}{l}\text { Faktör } \\
\text { Yükü }\end{array}$ & $\begin{array}{l}\bar{d} \\
\text { O্ষ } \\
\frac{d}{N} \\
: 0\end{array}$ & 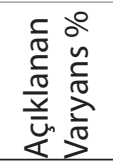 & 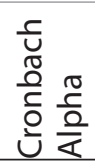 \\
\hline \multicolumn{7}{|l|}{ Faktör 1: İş İlanına Yönelik Tutum } \\
\hline Hoşuma gitmedi-Hoşuma gitti & 5,26 & 1,99 & 0,91 & & & \\
\hline Başarısız-Başarılı & 5,42 & 1,67 & 0,88 & & & \\
\hline Beğenmedim-Beğendim & 5,12 & 2,09 & 0,87 & 3,04 & 24,86 & 0,94 \\
\hline Kötü-lyi & 5,46 & 1,79 & 0,87 & & & \\
\hline Olumsuz-Olumlu & 5,34 & 1,91 & 0,86 & & & \\
\hline \multicolumn{7}{|l|}{ Faktör 2: İş Başvurusu Yapma Niyeti } \\
\hline $\begin{array}{l}\text { Süreç sonunda, bu pozisyon için iş teklifi alırsam kabul } \\
\text { ederim }\end{array}$ & 3,14 & 1,27 & 0,90 & & & \\
\hline Bu işe alınmak için elimden gelenin en iyisini yaparım & 2,94 & 1,31 & 0,88 & & & \\
\hline İlanda belirtilen işe başvuru yapabilirim & 2,87 & 1,31 & 0,88 & & & \\
\hline \multirow{2}{*}{$\begin{array}{l}\text { İlanda belirtilen işte çalışmayı isterim } \\
\text { İş görüşmesine çağrılırsam sürecinin tüm aşamalarına } \\
\text { katılırım }\end{array}$} & 2,84 & 1,28 & 0,87 & 6,55 & 29,01 & 0,92 \\
\hline & 3,26 & 1,31 & 0,86 & & & \\
\hline Bu firmanın başka ilanlarına da başvurmayı düşünürüm & 3,00 & 1,16 & 0,71 & & & \\
\hline Bu ilanı arkadaşlarıma da tavsiye ederim & 3,37 & 1,14 & 0,52 & & & \\
\hline \multicolumn{7}{|l|}{ Faktör 3: İlanın Bilgilendiriciliği } \\
\hline Bu ilan derinlemesine bilgi vermemektedir (ters kodlu). & 2,78 & 1,17 & 0,86 & & & \\
\hline Bu ilan kapsamlı değildir (ters kodlu). & 2,96 & 1,10 & 0,85 & & & \\
\hline İlanda daha fazla bilgi görmeyi tercih ederdim (ters kodlu). & 2,30 & 1,13 & 0,79 & 2,33 & 16,3 & 0,80 \\
\hline İlandan aldığım bilgi miktarı karar vermem için yeterlidir. & 3,04 & 1,09 & 0,57 & & & \\
\hline İlanda verilen bilgiler tatmin edicidir. & 3,17 & 1,03 & 0,53 & & & \\
\hline
\end{tabular}

\section{Manipülasyon Kontrolü}

Deneysel tasarımda yapılan manipülasyonun istendiği gibi çalışıp çalışmadığını değerlendirmek için, iş ilanının bilgilendiriciliği ortalama puanı açısından farklı versiyonlar arasında anlamlı bir farklılık olup olmadığı tek yönlü varyans analizi ve post-hoc karşılaştırmalar ile test edilmiştir. Buna göre, sunulan olanaklar bilgisine yer verilmeyen ilk versiyonda cevaplayıcılar tarafından algılanan bilgilendiricilik düzeyi ortalama puanı 2,67; genel ve muğlâk bilgiler verilen ikinci versiyonunda 3,02; belirgin ve ayrıntılı bilgiler verilen üçüncü versiyonunda 3,34'dür ve bu ortalamalar arasından anlamlı bir farklılık vardır $(F(2,597)=48,883, p<0,001)$.

Yapılan post-hoc LSD testinde ilk versiyon ile ikinci versiyon arasındaki-0,35 puanlıkfarkın anlamlı olduğu $(p<0,001)$, ilk versiyon ve üçüncü versiyon arasındaki $-0,67$ puanlık farkın anlamlı olduğu $(p<0,001)$, ikinci versiyon ve üçüncü versiyon arasındaki $-0,32$ puanlık farkın anlamlı olduğu $(p<0,001)$ belirlenmiştir. Buna göre, ayrıntılı bilgi verilen üçüncü versiyon, diğer iki versiyona göre daha bilgilendirici bulunmuştur.
Muğlak bilgi verilen ikinci versiyon ise, ilk versiyona göre daha bilgilendirici bulunmuştur. Bu sonuçlara göre ilandaki sunulan olanaklar bilgisi manipülasyonu istendiği gibi çalışmıştır.

\section{Hipotezlerin Test Edilmesi}

İş ilanı içinde çalışanlara sunulan olanaklara ilişkin bilgi sunulup sunulmamasının, adayların ilana yönelik tutumları üzerinde bir etkisinin olup olmadığını test etmek için $(\mathrm{H} 1 \mathrm{a})$, sunulan olanaklar hakkında bilgi içeren iş ilanına yönelik tutum ortalaması ile bu bilginin verilmediği ilana yönelik tutum ortalaması bağımsız iki örneklem t testi kullanılarak karşılaştırılmıştır. Benzer şekilde, iş ilanı içinde çalışanlara sunulan olanaklara ilişkin bilgi sunulup sunulmamasının, adayların ilandaki işe başvuru yapma niyetleri üzerinde bir etkisinin olup olmadığını test etmek için $(\mathrm{H} 1 \mathrm{~b})$ de $t$ testi kullanılmıştır. Tablo 2'de İş ilanına yönelik tutum ve ilandaki işe başvurma niyeti ortalamaları ve bu ortalamalar arasındaki farkın anlamlı olup olmadığını değerlendirmede kullanılan t testi sonuçları görülmektedir. 
Tablo 2: İş İlanında Çalışanlara Sunulan Olanaklar Bilgisine Yer Verip Vermemenin Etkisi

\begin{tabular}{|c|c|c|c|c|c|c|c|c|}
\hline Değiş̧kenler & $\begin{array}{l}\text { Sunulan } \\
\text { Olanaklar Bilgisi }\end{array}$ & $\mathrm{N}$ & Art. Ort & $\begin{array}{l}\text { Std. } \\
\text { Sapma }\end{array}$ & $\begin{array}{c}\text { Ort. Std. } \\
\text { Hatası }\end{array}$ & $\mathrm{t}$ & $\mathrm{Sd}$ & $p$ \\
\hline \multirow{2}{*}{$\begin{array}{l}\text { İş İlanına } \\
\text { Başvurma Niyeti }\end{array}$} & Bilgi Yok & 200 & 2,8350 & 94295 & 06668 & $-3,766$ & 598 & ,000 \\
\hline & Bilgi Var & 400 & 3,1693 & 1,06334 & ,05317 & & & \\
\hline \multirow{2}{*}{$\begin{array}{l}\text { İş İlanına Yönelik } \\
\text { Tutum }\end{array}$} & Bilgi Yok & 200 & 4,9860 & 1,56257 & 11049 & $-3,475$ & 598 & ,001 \\
\hline & Bilgi Var & 400 & 5,4835 & 1,69644 & ,08482 & & & \\
\hline
\end{tabular}

Tablodaki sonuçlara göre, çalışanlara sunulan olanaklar bilgisi içeren iş ilanına yönelik tutum ortalaması $\overline{\mathrm{X}}=5,48$ iken, bu bilginin olmadığı ilana yönelik tutum ortalaması $\overline{\mathrm{X}}=4,97$ 'dir. Bu iki ortalama arasındaki fark istatistiki olarak anlamlıdır $(t=-3,475 ; p=0,001)$. Bu bulguya göre, $\mathrm{H} 1 \mathrm{a}$ hipotezi doğrulanmıştır. Benzer şekilde, çalışanlara sunulan olanaklar bilgisi içeren iş ilanına başvuru yapma niyeti ortalaması $\overline{\mathrm{X}}=3,17$ iken, bu bilginin olmadığı ilana başvuru yapma niyeti ortalaması $\overline{\mathrm{X}}=2,84^{\prime}$ tür. Bu iki ortalama arasındaki fark istatistiki olarak anlamlıdır $(t=-3,766 ; p<0,001)$. Bu bulguya göre, $\mathrm{H} 1 \mathrm{~b}$ hipotezi de doğrulanmıştır. Çalışanlara sunulan olanaklar hakkında bilgi içeren iş ilanları, bu bilgiyi içermeyen ilanlara göre hem daha olumlu değerlendirilmekte, hem de bu ilanlara başvuru yapma niyeti daha yüksek olmaktadır.
Iş ilanı içinde çalışanlara sunulan olanaklara ilişkin bilginin ayrıntı derecesinin, adayların ilana yönelik tutumları üzerinde bir etkisinin olup olmadığını test etmek için ( $\mathrm{H} 2 \mathrm{a})$, sunulan olanaklar hakkında genel ifadeler içeren iş ilanına yönelik tutum ortalaması ile bu bilginin ayrıntılı ve somut bir şekilde verildiği ilana yönelik tutum ortalaması bağımsız iki örneklem t testi kullanılarak karşılaştırılmıştır. Benzer şekilde, iş ilanı içinde çalışanlara sunulan olanaklara ilişkin bilginin ayrıntı derecesinin, adayların ilandaki işe başvuru yapma niyetleri üzerinde bir etkisinin olup olmadığını test etmek için $(\mathrm{H} 2 \mathrm{~b})$ de $\mathrm{t}$ testi kullanılmıştır. Tablo 3'de, bilginin ayrıntı derecesi açısından iki farkı ilanı okuyan cevaplayıcıların, iş ilanına yönelik tutum ve ilandaki işe başvurma niyeti ortalamaları ve bu ortalamalar arasındaki farkın anlamlı olup olmadığını değerlendirmede kullanılan $t$ testi sonuçları görülmektedir.

Tablo 3: İş Illanında Çalışanlara Sunulan Olanaklar Bilgisinin Ayrıntı Derecesinin Etkisi

\begin{tabular}{llccccccc}
\hline Değişkenler & $\begin{array}{l}\text { Sunulan Olanaklar } \\
\text { Bilgisi }\end{array}$ & $\mathrm{N}$ & Art. Ort & $\begin{array}{c}\text { Std. } \\
\text { Sapma }\end{array}$ & $\begin{array}{c}\text { Ort. Std. } \\
\text { Hatası }\end{array}$ & $\mathrm{t}$ & $\mathrm{Sd}$ & $\mathrm{p}$ \\
\hline $\begin{array}{l}\text { Iş̧ Illanına } \\
\text { Başvurma Niyeti }\end{array}$ & Genel Bilgi & 200 & 3,0200 & 1,07803 &, 07623 & $-2,832$ & 398 &, 005 \\
& Ayrıntılı Bilgi & 200 & 3,3186 & 1,02963 &, 07281 & & & \\
\hline $\begin{array}{l}\text { Iş̧ Illanına Yönelik } \\
\text { Tutum }\end{array}$ & Genel Bilgi & 200 & 5,3280 & 1,75597 &, 12417 & $-1,839$ & 398 &, 067 \\
& Ayrıntılı Bilgi & 200 & 5,6390 & 1,62428 &, 11485 & & &
\end{tabular}

Tablodaki sonuçlara göre, çalışanlara sunulan olanaklar bilgisinin detaylı bir şekilde verildiği iş ilanına yönelik tutum ortalaması $\overline{\mathrm{X}}=5,64$ iken, bu bilginin genel ve belirsiz ifadelerle verildiği ilana yönelik tutum ortalaması $\overline{\mathrm{X}}=5,33^{\prime}$ tür. Bu iki ortalama arasındaki fark istatistiki olarak anlamlılık sınırının biraz üzerindedir ( $t=-1,839 ; p=0,067)$. Bu bulguya göre, $\mathrm{H} 2 \mathrm{a}$ hipotezini doğrulayacak yeterli kanıta ulaşılamamıştır. Diğer taraftan, çalışanlara sunulan olanaklar bilgisinin ayrıntılı bir şekilde verildiği iş ilanına başvuru yapma niyeti ortalaması $\bar{X}=3,32$ iken, bu bilginin muğlak ve belirsiz ifadelerle verildiği 
ilana başvuru yapma niyeti ortalaması $\bar{X}=3,02$ 'dir. $\mathrm{Bu}$ iki ortalama arasındaki fark istatistiki olarak anlamlıdır ( $\mathrm{t}=-2,832 ; \mathrm{p}=0,005)$. Bu bulguya göre, $\mathrm{H} 2 \mathrm{~b}$ hipotezi doğrulanmıştır. Çalışanlara sunulan olanaklar hakkında ayrıntılı ve somut bilgi içeren iş ilanları, bu bilgiyi belirsiz ve muğlak ifadelerle veren ilanlara göre daha yüksek bir başvuru yapma niyeti ortaya çıkarmaktadır.
Bir sonraki aşamada, ilandaki bilginin ayrıntı düzeyinin yanında, cevaplayıcıların mezuniyet durumunda olup olmaması da ikinci bir bağımsız değişken olarak ele alınmış ve iki faktörlü varyans analizi gerçekleştirilmiştir. Tablo 4'te farklı içerikteki iş ilanlarına yönelik tutum ve iş başvurusu yapma niyeti ortalamalarının cevaplayıcının mezuniyet durumuna dağılımları görülmektedir.

Tablo 4: İlan Türü ve Mezuniyet Durumuna Göre Illana Yönelik Tutum ve İ̧̧ Başvurusu Yapma Niyeti Ortalamaları

\begin{tabular}{|c|c|c|c|c|c|}
\hline Bağımlı Değişken & $\begin{array}{l}\text { Faktör 1: } \\
\text { illan Türü }\end{array}$ & $\begin{array}{l}\text { Faktör 2: Mezuniyet } \\
\text { Durumu }\end{array}$ & Art.Ort. & Std. Sp. & $\mathrm{N}$ \\
\hline \multirow{9}{*}{ İş İlanına Başvurma Niyeti } & \multirow{3}{*}{$\begin{array}{l}\text { Sunulan Olanaklar Bilgisi } \\
\text { Yok }\end{array}$} & Alt Sınıflar & 2,9980 & ,86515 & 140 \\
\hline & & Son Sinıf & 2,4548 & 1,01271 & 60 \\
\hline & & Toplam & 2,8350 & ,94295 & 200 \\
\hline & \multirow{3}{*}{ Genel Bilgi } & Alt Sınıflar & 3,1300 & 1,01852 & 145 \\
\hline & & Son Sinıf & 2,7299 & 1,18241 & 55 \\
\hline & & Toplam & 3,0200 & 1,07803 & 200 \\
\hline & \multirow{3}{*}{ Ayrıntılı Bilgi } & Alt Sınıflar & 3,2908 & 1,03923 & 141 \\
\hline & & Son Sınıf & 3,3850 & 1,01198 & 59 \\
\hline & & Toplam & 3,3186 & 1,02963 & 200 \\
\hline \multirow{9}{*}{ İş İlanına Yönelik Tutum } & \multirow{3}{*}{$\begin{array}{l}\text { Sunulan Olanaklar Bilgisi } \\
\text { Yok }\end{array}$} & Alt Sınıflar & 5,1657 & 1,53781 & 140 \\
\hline & & Son Sınıf & 4,5667 & 1,55189 & 60 \\
\hline & & Toplam & 4,9860 & 1,56257 & 200 \\
\hline & \multirow{3}{*}{ Genel Bilgi } & Alt Sınıflar & 5,2897 & 1,84209 & 145 \\
\hline & & Son Sinıf & 5,4291 & 1,51654 & 55 \\
\hline & & Toplam & 5,3280 & 1,75597 & 200 \\
\hline & \multirow{3}{*}{ Ayrıntılı Bilgi } & Alt Sınıflar & 5,7589 & 1,58250 & 141 \\
\hline & & Son Sinif & 5,3525 & 1,69963 & 59 \\
\hline & & Toplam & 5,6390 & 1,62428 & 200 \\
\hline
\end{tabular}

Alt sınıflarda okuyan öğrencilerin genel ve muğlak bilgi içeren ilana başvuru niyeti ortalaması ( $\bar{X}=3,13)$, mezuniyet aşamasındaki son sınıf öğrencilerinkinden $(\bar{X}=2,72)$ daha yüksektir. Diğer taraftan, mezuniyet aşamasındaki son sınıföğrencilerinin ayrıntılıve somut bilgiler içeren ilana başvuru yapma niyeti ortalaması ( $\bar{X}=3,39)$, alt sınıflarda okuyan öğrencilerinkinden ( $\bar{X}=3,29)$ daha yüksektir. Diğer taraftan, alt sınıflarda okuyan öğrencilerin genel ve muğlak bilgi içeren ilana yönelik tutum ortalaması ( $\bar{X}=5,29$ ), mezuniyet aşamasındaki son sınıf öğrencilerinkinden ( $\bar{X}$ $=5,43$ ) daha düşüktür. Mezuniyet aşamasındaki son sınıf öğrencilerinin ise ayrıntılı ve somut bilgiler içeren ilana yönelik tutum ortalaması $(\bar{X}=5,35)$, alt sınıflarda okuyan öğrencilerinkinden ( $\bar{X}=5,76)$ daha düşüktür.
Bu farklılıkların anlamlı olup olmadığını görebilmek için iki bağımlı değişkenli (iş ilanına yönelik tutum ve ilandaki işe başvurma niyeti) iki faktörlü (ilan türü ve mezuniyet durumu) varyans analizi yapılmıştır. Bu analiz öncesinde, Levene testi ile farklı gruplardaki varyansların homojen olduğu doğrulanmıştır. Yapılan çok faktörlü varyans analizi sonuçlarına göre, farklı ilan türlerini gören cevaplayıcıların bağımlı değişkenlere verdikleri yanıtların ortalamaları arasındaki farklar istatistiki olarak anlamlıdır (Wilk's Lambda $=0,939 ; \mathrm{F}_{(4,1186)}=9,482$; $\mathrm{p}<0,001)$. Benzer şekilde, mezuniyet açısından farklı durumdaki cevaplayıcıların bağımlı değişkenlere verdikleri yanıtların ortalamaları arasındaki farklar da istatistiki olarak anlamlıdır (Wilk's Lambda=0,982; $\left.F_{(2,593)}=5,364 ; p=0,005\right)$. Bu iki bağımsız değişkenin 
etkileşimi durumunda da, cevaplayıcıların bağımlı değişkenlere verdikleri yanıtların ortalamaları arasındaki farklar istatistiki olarak anlamlıdır (Wilk's Lambda=0,974; $\left.\quad F_{(4,1186)}=3,860 ; \quad p=0,004\right)$.
Gruplar arasındaki bu farklılıkların hangi bağımlı değişkenlerden kaynaklandığını görebilmek için tek değişkenli (univariate) varyans analizi sonuçları da incelenmiştir. Bu sonuçlar Tablo 5'te görülmektedir.

Tablo 5: Çok Faktörlü Varyans Analizi Tek Değişkenli Testler Tablosu

\begin{tabular}{|c|c|c|c|c|c|c|c|}
\hline Faktörler & Bağımlı Değişkenler & $\begin{array}{l}\text { Tip III Kareler } \\
\text { Toplamı }\end{array}$ & $\mathrm{Sd}$ & $\begin{array}{l}\text { Ortalamanın } \\
\text { Karesi }\end{array}$ & $\mathrm{F}$ & $p$ & $\eta^{2}$ \\
\hline \multirow{2}{*}{ Düzeltilmiş Model } & İşe Başvurma Niyeti & $42,962 a$ & 5 & 8,592 & 8,506 & ,000 & ,067 \\
\hline & İlana Yönelik Tutum & $65,387 b$ & 5 & 13,077 & 4,850 & ,000 & ,039 \\
\hline \multirow{2}{*}{ Intercept } & İşe Başvurma Niyeti & 4436,942 & 1 & 4436,942 & 4392,354 & ,000 & ,881 \\
\hline & İlana Yönelik Tutum & 13659,727 & 1 & 13659,727 & 5065,522 &, 000 & ,895 \\
\hline \multirow{2}{*}{ TUR } & İşe Başvurma Niyeti & 32,355 & 2 & 16,178 & 16,015 &, 000 & 051 \\
\hline & İlana Yönelik Tutum & 42,175 & 2 & 21,088 & 7,820 &, 000 & ,026 \\
\hline \multirow{2}{*}{ MEZUNIYET } & İşe Başvurma Niyeti & 9,887 & 1 & 9,887 & 9,788 & ,002 & 016 \\
\hline & İlana Yönelik Tutum & 10,282 & 1 & 10,282 & 3,813 & 051 & ,006 \\
\hline \multirow{2}{*}{ TUR x MEZUNIYET } & İşe Başvurma Niyeti & 9,309 & 2 & 4,655 & 4,608 & ,010 & 015 \\
\hline & İlana Yönelik Tutum & 11,924 & 2 & 5,962 & 2,211 & 111 & ,007 \\
\hline \multirow{2}{*}{ Hata } & İşe Başvurma Niyeti & 600,030 & 594 & 1,010 & & & \\
\hline & İlana Yönelik Tutum & 1601,785 & 594 & 2,697 & & & \\
\hline \multirow{2}{*}{ Toplam } & İşe Başvurma Niyeti & 6253,286 & 600 & & & & \\
\hline & İlana Yönelik Tutum & 18633,720 & 600 & & & & \\
\hline \multirow{2}{*}{$\begin{array}{l}\text { Düzeltilmiş } \\
\text { Toplam }\end{array}$} & İşe Başvurma Niyeti & 642,992 & 599 & & & & \\
\hline & İlana Yönelik Tutum & 1667,173 & 599 & & & & \\
\hline
\end{tabular}

a. $R^{2}=, 067$ (Düzeltilmiş $R^{2}=, 059$ )

b. $R^{2}=, 039$ (Düzeltilmiş $R^{2}=, 031$ )

Cevaplayıcıların gördüğü iş ilanı türünün, hem ilandaki işe başvuru yapma niyeti $\left(F_{(2 ; 594)}=16,015\right.$; $P<0,001)$, hem de iş ilanına yönelik tutum $\left(F_{(2 ; 594)}=\right.$ 7,820; $P<0,001)$ üzerinde anlamlı bir doğrudan etkisi vardır. Cevaplayıcıların mezuniyet durumunun, ilandaki işe başvuru yapma niyeti üzerinde anlamlı bir doğrudan etkisi vardır $\left(\mathrm{F}_{(1 ; 594)}=9,788 ; \mathrm{P}=0,002\right)$, ancak iş ilanına yönelik tutum üzerindeki doğrudan etkisi anlamlı değildir $\left(F_{(1 ; 594)}=3,813 ; P=0,051\right)$. İş ilanı türü ve mezuniyet durumu etkileşim terimi, ilandaki işe başvuru yapma niyeti üzerinde anlamlı bir etkiye sahiptir $\left(F_{(2 ; 594)}=4,608 ; P=0,01\right)$, ancak bu etkileşim teriminin iş ilanına yönelik tutum üzerindeki etkisi anlamlı değildir $\left(\mathrm{F}_{(2 ; 594)}=2,211 ; \mathrm{P}=0,111\right)$. Bu sonuçlara göre H3b doğrulanırken, H3a'yı destekleyecek yeterli kanıta ulaşılamamıştır.
Belirlenen bu etkilerin daha net görülebilmesi için, her bağımlı değişken için verilen yanıtların ortalamaları bir grafik haline getirilmiş ve aşağıda Grafik 1'de sunulmuştur. Grafikte görüldüğü gibi, çalışanlara sunulan olanaklar bilgisi ayrıntılı bir şekilde verildiğinde, son sınıfta okuyan cevaplayıcıların iş ilanına başvurma niyeti, alt sınıflarda okuyanlara göre daha fazla bir şekilde artmaktadır. Diğer taraftan, son sınıfta okuyan mezuniyet aşamasındaki cevaplayıcılar, çalışanlara sunulan olanaklar bilgisinin genel ifadelerle anlatıldığı ilanı diğer iki versiyona göre daha olumlu değerlendirmişlerdir. Alt sınıflarda okuyan cevaplayıcılar ise, iş ilanına yönelik tutum açısından en yüksek puanları ayrıntılı bilgi içeren versiyona vermişlerdir. 
Grafik 1. Illan Türü ve Mezuniyet Durumuna Göre İş Illanına Yönelik Tutum ve Başvuru Yapma Niyeti

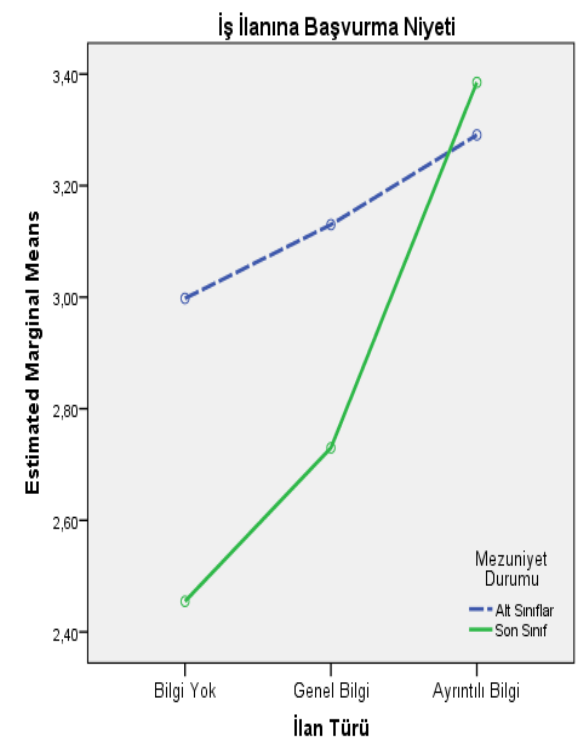

\section{TARTIŞMA}

Bu çalışmada, iş ilanlarında çalışanlara sunulan olanaklar bilgisini farklı şekillerde vermenin, ilanın çekiciliğini nasıl etkilediği incelenmiştir. İlanda bu bilgiyi verip vermemenin, ilana yönelik tutum ve ilandaki işe başvuru yapma niyetini değiştirip değiştirmediği deneysel bir araştırma ile incelenmiştir. Yapılan analizler sonucunda, iş ilanlarında çalışanlara sunulan olanaklara ilişkin bilgiler verilmesinin, ilana yönelik tutum ve iş başvurusu yapma niyetini farklılaştırdığı belirlenmiştir. Bu bilgiyi genel ve muğlak ifadeler yerine, ayrıntılı bir şekilde ve somut ifadelerle sunmanın, ilandaki işe başvuru yapma niyetini daha da arttırdığı ortaya konmuştur.

Bu bulgular, iş ilanlarında mesaj belirginliğinin olumlu etkisini ortaya koyan önceki çalışmaların bulgularını desteklemektedir (Acarlar ve Bilgiç, 2013; Turban vd., 1998; Barber ve Roehling 1993; Kaplan vd., 1991). Bununla birlikte, bu araştırmanın sonuçları, Feldman vd. (2006) ile Roberson vd.'nin (2005) bulgularından bazı farklılıklar göstermektedir. Roberson vd., (2005) iş ilanındaki mesaj belirginliğinin örgütsel özellikler ve kişi örgüt uyumu algılamalarını olumlu yönde etkilerken, algılanan örgütsel çekicilik üzerinde anlamlı bir etkisi olmadığını belirlemiştir.

Feldman vd. (2006) iş ilanında ayrıntılı bilgi sunmanın, iş ilanının inandırıcılığı ve bilgilendirme düzeyi, iş ilanına yönelik tutum ve örgüte yönelik

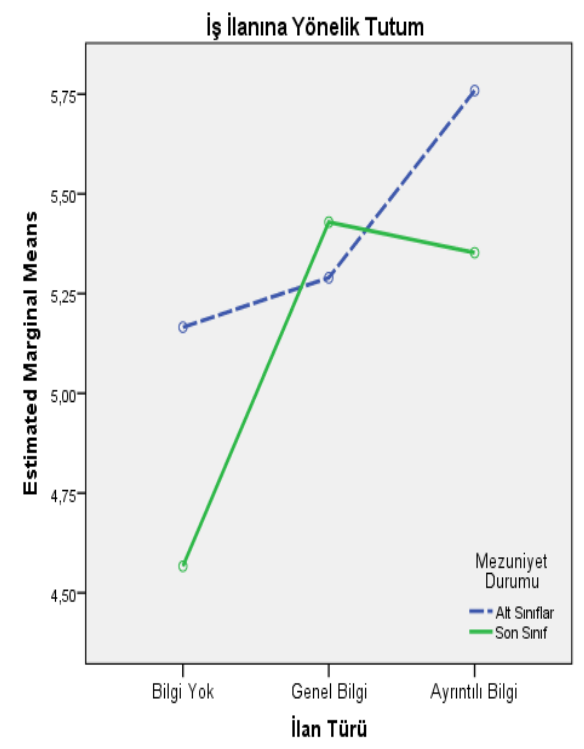

tutum üzerinde anlamlı bir etkisi olduğunu ancak ilandaki işe yönelik başvuru yapma ve iş görüşmesi sürecine devam etme niyeti üzerinde anlamlı bir etkisinin olmadığını belirlemiştir. Bu çalışma, ayrıntılı bilgi içeren iş ilanlarının, adayların ilana başvuru yapma niyetini de artırdığını ortaya koymuştur. Bu farklılığın olası nedeni, araştırmaların farklı sosyoekonomik koşullara sahip ülkelerde gerçekleştirilmesi olabilir.

İş ilanında çalışanlara sunulan olanaklara ilişkin bilgiler vermenin, ilana yönelik tutumu da olumlu yönde etkilediği belirlenmiştir. İçinde bu bilgiye yer verilen ilanlara yönelik tutum ortalaması, bu bilgiyi içermeyen ilanlara yönelik tutum ortalamasından daha yüksektir. Ancak, iş ilanına yönelik tutum açısından genel bilgiler içeren ilan ile ayrıntılı bilgiler içeren iş ilanları arasında anlamlı bir farklıık bulunamamıştır. Cevaplayıcılar, her iki türde iş ilanına yönelik tutum açısından ortalamanın üzerinde puanlar almışlardır.

Bu bulguların, insan kaynakları yönetimi literatürüne özellikle ulusal ölçekte anlamlı katkılar yapma potansiyeli bulunmaktadır. Bilgi içeriği açısından farklı iş ilanlarının potansiyel çalışanları nasıl etkilediği konusunda sınırlı sayıdaki ulusal araştırmadan biri olarak bu çalışma, daha etkili iş ilanları hazırlama konusunda uygulamacılara da yol gösterici bilgiler sunmaktadır. 
Yayınladıkları iş ilanları ile daha geniş bir aday havuzu oluşturmak isteyen işletmeler, bu ilanlarda çalışanlara sunulan olanaklar bilgisine yer vermeli, bu bilgiyi genel ve jenerik ifadeler yerine ayrıntılı, somut ve belirgin ifadeler kullanarak sunmalıdırlar.

Büyük ölçekli, güçlü bir kurumsal itibara sahip ve herkesçe tanınan işletmeler dışında kalan diğer işletmeler, yayınlayacakları iş ilanlarında bu konuya özellikle dikkat etmelidirler. Zira adaylar, bu tür işletmelere ilişkin bilgi eksiklerinin bir kısmını, iş ilanlarının içinde sunulan bilgilerle telafi etme eğiliminde olacaklardır. İnsan kaynakları bölümü yöneticileri daha ayrıntılı bilgi içeren, dolayısıyla daha geniş bir alan gerektiren iş ilanları için katlanacakları ek maliyet karşılığında daha zengin aday havuzu elde edebileceklerdir. En azından, iş gücü piyasasına yeni giriş yapacak olan üniversite öğrencilerinin, bu tür ayrıntılı bilgiler içeren ilanlara yönelik tutumları daha olumlu ve başvuru yapma niyetleri daha yüksektir.

\section{Araştırmanın Sınırları ve Gelecek Araştırmalar İçin Öneriler}

Bu araştırmanın bulguları değerlendirilirken bazı önemli sınırlııklar da göz önüne alınmalıdır. Her şeyden önce, kolayda örnekleme yöntemiyle seçilen üniversiteöğrencilerinin kullanılması, bulguların dışsal geçerliliği üzerinde önemli bir kısıttır. Ancak benzer alanlarda eğitim gören üniversite öğrencilerinin farklı deney gruplarına rastgele atanması, deneyin içsel geçerliliğini güçlendirmektedir. Diğer yandan, işgücü pazarının en önemli girdileri olan üniversite öğrencilerinin kullanılması, incelenen nedensellik ilişkilerinin gerçekçi bir şekilde değerlendirilmesinin önünde bir engel değildir. Günümüzde pek çok şirket, üniversite kampüslerinde düzenlenen kariyer günü etkinliklerine katılarak buralardan kendilerine çalışan seçmeye başlamıştır. Bununa birlikte, bu çalışmanın, genç ve profesyonel çalışma deneyimi çok az olan üniversite öğrencileri dışında, halihazırda bir kurumda aktif olarak çalışan deneyimli işgörenler üzerinde de tekrarlanması gerekmektedir.

Bu çalışmada sadece IïBF ve Illetişim Fakültesi öğrencilerinden toplanan bilgiler analiz edilmiştir. Fen, mühendislik, mimarlık, tıp ve güzel sanatlar gibi farklı alanlarda okuyan öğrencilerin benzer bir çalışma kapsamında incelenmesi, sonuçların karşılaştırılması olanağı sağlayabilir.

Bir başka önemli kısıt ise, iş ilanındaki mesaj belirginliğinin kurgusal bir çerçevede incelenmesinden kaynaklanan yapaylıktır. Daha doğal bir çerçevede, iş arayanların farklı içerikteki iş ilanlarına yönelik tepkilerinin nasıl olduğunun da incelenmesi yerinde olacaktır. Bunun için özellikle çevrimiçi kariyer siteleri ile işbirliği yaparak, gerçek dünyada iş arayan adayların farklı ilanlara verdikleri gerçek davranışsal tepkiler analiz edilebilir.

$\mathrm{Bu}$ çalışmadaki iş ilanında, yeni mezunlar için başlangıç düzeyindeki bir iş incelenmiştir. Kariyer sürecinin daha üst basamaklarındaki profesyoneller için farklı pozisyonlar söz konusu olduğunda ilandaki mesaj belirginliğinin nasıl bir etki ortaya çıkaracağının da incelenmesi yerinde olacaktır.

Bu çalışmada, iş ilanını veren firmanın ismi özellikle gizlenmiştir. Bu şekilde, cevaplayıcıların ilanı veren kuruma yönelik mevcut algılamaları ve tutumlarının, ilandaki bilgi miktarının etkisini gölgelemesinin önüne geçilmesi amaçlanmıştır.

Fakat unutulmamalıdır ki, iş ilanlarının çekiciliğini belirleyen önemli bir unsur da ilanı veren kurumun itibarıdır. Ileride yapılacak çalışmalarda, gerçek dünyadan alınmış ve kurum ismi de içeren ilanlar kullanılarak, algılanan kurumsal itibarın iş ilanlarına verilen tepkiler üzerinde nasıl bir etkisi olduğu incelenmelidir.

Araştırma için oluşturulan hipotetik ilanlarda sadece çalışanlara sunulan olanaklar bilgisi maniple edilmiştir. İşin tanımı, adaylarda aranan özellikler gibi ilanın diğer önemli bileşenlerindeki bilginin ayrıntı düzeyi değiştirildiğinde ne tür sonuçlar ortaya çıkacağı konusu ileriki araştırmalarda cevaplanması gereken bir başka soru olarak durmaktadır. Son olarak; iş ilanının içeriği dışında, özellikle ilanın yayınlandığı mecranın, ilanın estetik/fiziksel unsurlarının ve ilanda kullanılan dilin iknaya etkisinin ayrıntılı bir şekilde incelenmesi gerekmektedir. Bu alanlarda henüz cevaplanmamış çok sayıda soru bulunmaktadır. 


\section{KAYNAKÇA}

Aaker, D.A., ve D.M. Stayman (1990), "Measuring Audience Perceptions of Commercials and Relating Them to Ad Impact," Journal of Advertising Research, 30(3): 7-17.

Abernethy, A.M. ve G.R. Franke (1996), "The Information Content of Advertising: A Meta-Analysis," Journal of Advertising, 25 (3): 1-17.

Acarlar, G., ve R. Bilgic, (2013), "Factors influencing applicant willingness to apply for the advertised job opening: the mediational role of credibility, satisfaction and attraction", The International Journal of Human Resource Management, 24(1): 50-77.

Allen, D., Van Scotter, J., \& Otondo, R. (2004), "Recruitment communication media: Impact on prehire outcomes" Personnel Psychology, 57: 143-171.

Barber, A.E., and Roehling, M.V., (1993), "Job Postings and the Decision to Interview: A Verbal Protocol Analysis" Journal of Applied Psychology, 78: 845-856.

Baş, T., A.Ü., Aydınlık, F. Erenel, (2011), “Üniversite Öğrencilerinin İşveren Seçim Kriterlerinin Belirlenmesine Yönelik Keşfedici Bir Araştırma", Ege Akademik Bakış, 11(3): 439-452.

Belt, A., \& Paolillo, J. (1982), "The influence of corporate image and specificity of candidate qualifications on response to recruitment advertisement", Journal of Management, 8: 105-112.

Breaugh, J. A. (2005), “Employee recruitment: Current knowledge and important areas for future research" Human Resource Management Review, 18: 103-118.

Breaugh, J. A., ve Starke, M. (2000), "Research on employee recruitment: So many studies, so many remaining questions, Journal of Management, 26(3): 405-430.

Blackman, A. (2006), “Graduating Students' Responses to Recruitment Advertisements" Journal of Business Communication, 43(4): 367-388.

Breaugh, J. A., \& Billings, R. S. (1988), "The realistic job preview: Five key elements and their importance for research and practice" Journal of Business and Psychology, 2: 291-305.

Cable, D.M., Aiman-Smith, L., Mulvey, P.W., ve Edwards, J.R., (2000), "The Sources and Accuracy of Job Applicants' Beliefs About Organizational Culture" Academy of Management Journal, 43: 1076-1085.

Cable, D.M. ve M.E. Graham, (2000), “The Determinants of Job Seekers' Reputation Perceptions," Journal of Organizational Behavior, 21(12): 929-947.

Capelli, P., (2001), "Making the Most of On-line Recruiting" Harvard Business Review, 79(3): 139-146.
Dowling, G.R., (1988), "Measuring Corporate Images: A Review of Alternative Approaches" Journal of Business Research, 17(8): 27-34.

Erdem, B., T., Gezen, (2014), "Turizm İşletmelerine Yönelik İş İlanlarının İçerik Analizi Yöntemiyle Incelenmesi", Uluslararası Yönetim iktisat ve İsletme Dergisi, 10(21):19-42.

Feldman, D.C., Bearden, W.O., ve Hardesty, D.M. (2006), "Varying the Content of the Job Advertisements: The Effects of Message Specificity" Journal of Advertising, 35: 123-141.

Feldman D.C. ve Brian S. Klaas, (2002), "Internet Job Hunting: A Field Study of Applicant Experiences with On-line Recruiting" Human Resource Management, 41(Summer): 175-192.

Fernandez, K.V.veD.L. Rosen, (2000), “TheEffectiveness of Information and Color in Yellow Pages Advertising" Journal of Advertising, 29(Summer), 61-73.

Fisher, C.D., Ilgen, D.R., ve Hoyer, W.D., (1979), "Source Credibility, Information Favorability, and Job Offer Acceptance" Academy of Management Journal, 22: 94-103.

Gatewood, R.D., ve H.S. Field, (1998), Human Resource Selection, 4th ed., Orlando, FL: Dryden Press.

Gatewood, R.D., Gowan, M.A., ve Lautenschlager, G.J., (1993), "Corporate Image, Recruitment Image, and Initial Job Choice Decisions" The Academy of Management Journal, 36: 414-427.

Goltz, S.M., C.M. Giannantonio, (1995), "Recruiter Friendliness and Attraction to the Job: The Mediating Role of Inferences about the Organization", Journal of Vocational Behavior, 46(1): 109-118.

Highhouse, S., Zickar, M., Thorsteinson, T., Steirwalt, S., \& Slaughter, J. (1999), "Assessing company employment image: An example in the fast food industry" Personnel Psychology, 52: 151-172.

Kaplan, A.B., M.G. Aamodt, ve D. Wilk, (1991), "The Relationship Between Advertisement Variables and Applicant Responses to Newspaper Recruitment Advertisements" Journal of Business and Psychology, 5 (3): 383-395.

Lee, C.-H., F.-M. Hwang, Yu-Chen Yeh, (2013), "The impact of publicity and subsequent intervention in recruitment advertising on job searching freshmen's attraction to an organization and job pursuit intention" Journal of Applied Social Psychology, 43: $1-13$.

MacKenzie, S.B. (1986), "The Role of Attention in Mediating the Effect of Advertising on Attribute 
Importance," Journal of Consumer Research, 13 (September): 174-195.

Mason, N., ve J.A. Belt (1986), "Effectiveness of Specificity in Recruitment Advertising," Journal of Management, 12(September): 425-432.

Maurer, S.D., V. Howe, ve T.W. Lee (1992), "OrganizationalRecruitingas Marketing Management: An Interdisciplinary Study of Engineering Graduates," Personel Psychology, 45(Winter): 807-834.

Neely-Martinez, M., (2002) "Breaking the mold", HR Magazine, 46: 82-90.

Ogilvy, D., (1983), Ogilvy on Advertising, New York: Crown.

Powell, G.N. (1984), "Effect of Job Attributes and Recruiting Practices on Applicant Decisions: A Comparison," Personel Psychology, 37 (Winter): 721732.

Premack, S.L., ve J.P. Wanous, (1986), "A Meta-Analysis of Realistic Job Preview Experiments," Journal of Applied Psychology, 70(November): 706-719.

Rafaeli, A., ve Amalya L.O., (1998), “Employment Ads: A Configurational Research Agenda," Journal of Management Inquiry, 7 (December): 342-358.

Reeve, C.L., ve Schultz, L. (2004), "Job-Seeker Reactions to Selection Process Information in Job Ads" International Journal of Selection and Assessment, 12: 343-355.

Roberson, Q.M. C.J. Collins, S. Oreg, (2005), "The Effects of Recruitment Message Specificity on Applicant Attraction to Organizations", Journal of Business and Psychology, 19(3): 319-339.

Roehling, M.V. (2002), "The "good cause" norm in employment relations: Empirical evidence and policy implications", Employee Responsibilities and Rights Journal, 14: 91-104.

Ryan, A.M., ve R.E. Ployhart, (2000), "Applicants' Perceptions of Selection Procedures and Decisions: A Critical Review and Agenda for the Future," Journal of Management, 26(3): 565-606.

Rynes, S.L., (1991), "Recruitment, Job Choice, and Post-Hire Consequences: A Call for New Research Directions," in Handbook of Industrial and Organizational Psychology, M.D. Dunnette ve L.M. Hough, Eds., Palo Alto, CA: Consulting Psychologists Press.Rynes, S.L.; Miller, H.E., (1983), “Recruiter and job influences on candidates for employment", Journal of Applied Psychology, 68(1): 147-154.

Schneider, B.D. B. Smith, ve H.W. Goldstein, (2000), "Attraction-Selection-Attrition: Toward a PersonEnvironment Psychology of Organizations,"in PersonEnvironment Psychology, W.B. Walsh, K.H. Craik, ve R.H. Price, Eds., Mahwah, NJ: Lawrence Erlbaum.

Snyder, R., (1989), "Misleading Characteristics of Implied-Superiority Claims," Journal of Advertising, 18(4): 54-61.

Taylor, M.S., \& Bergmann, T.J., (1987), “Organizational recruitment activities and applicants' reactions at different stages of the recruitment process", Personnel Psychology, 40: 261-285.

Thorsteinson, T., \& Highhouse, S., (2003), “Effects of goal framing in job advertisements on organizational attractiveness", Journal of Applied Social Psychology, 33(11): 2393-2412.

Turban, D., Forret, M., \& Hendrickson, C., (1998), "Applicant attraction to firms: Influences of organization reputation, job and organizational attributes, and recruiter behaviors", Journal of Vocational Behavior, 52: 24-44.

Turban D.B., ve D.W. Greening, (1996), "Corporate Social Performance and Organizational Attractiveness to Prospective Employees," Academy of Management Journal, 40 (June): 658-672.

Van Hoye, G., \& Lievens, F., (2005), "Recruitmentrelated information sources and organizational attractiveness: Can something be done about negative publicity?", International Journal of Selection and Assessment, 13:179-187.

Walker, H.J., Feild, H.S., Giles, W.F., \& Bernerth, J.B., (2008), "The interactive effects of job advertisement characteristics and applicant experience on reactions to recruitment messages", Journal of Occupational and Organizational Psychology, 81: 619- 638.

Wanous, J.P., (1978), "Realistic Job Previews: Can a Procedure to Reduce Turnover Also Influence the Relationship between Abilities and Performance?" Personnel Psychology, 31: 249-258.

Yüce, P. ve Highhouse, S., (1998), "Effects of Attribute Set Size and Pay Ambiguity on Reactions to "Help Wanted" Advertisements", Journal of Organizational Behavior, 19: 337-352. 


\section{EK-1 ARAŞTIRMADA KULLANILAN iş ILANI}

\section{BANKA - MÜŞTERI TEMSILCisi}

\section{(ref: MT35)}

\section{StratejiK Insan Kaynakları Danısmanlkk Hizm. Ltd. Sti}

\section{Stratej IK}

Danışmanlığını yapmakta olduğumuz Türkiye'nin önde gelen bankalarından

birinde görev alacak 'Müşteri Temsilcileri' arıyoruz.

\section{Aranan Özellikler:}

- Üniversitelerin 4 yıllık eğitim veren bölümlerinde okuyan ya da mezun

- 29 yaşını aşmamış, erkek adaylar için askerlik hizmetini tamamlamış ya da en az 2 yıl tecilli

- İletişim ve ikna becerileri gelişmiş

- Satış konusunda istekli

- Bankacılık alanında kariyer hedefleyen

- Tercihen yazılı ve sözlü iletişim kurabilecek düzeyde İngilizce bilgisine sahip

- Hedef odaklı ve takım çalışmasına yatkın

\section{İş Tanımı:}

- Bireysel müşterilere, etkili müşteri iletişimi ve mükemmel hizmet kalitesi ile tüm bireysel bankacılık ürün ve hizmetlerini sunmak

- Satış sürecini etkin yöneterek, müşterilerimizin ihtiyaç ve taleplerini tespit etmek

- Mevcut müşteri ilişkilerinin geliştirilmesi ve potansiyel müşterilerin kazanımında katma değer yaratmak

- Müşterilerin intiyaç ve taleplerinin tespitini yaparak, müşteri odaklı yaklaşım getirebilmek

- Sürdürülebilir müşteri memnuniyeti sağlamak

\section{Sunulan Olanaklar:}

- Ayda 2000 TL'den başlayan maaş olanağı

- İkişer yıllık periyotlarda performansa dayalı olarak terfi olanağı

- Performans ve hedeflere bağlı olarak yılda 4 maaşa kadar ikramiye.

- Kurum içi sertifikalı eğitim programları ve anlaşmalı eğitim kurumlarında MBA yapma imkanı

- Öğle yemeği, servis, özel sağlık sigortası, evlilik ve çocuk yardımı gibi sosyal destekler

\section{Pozisyon Hakkındaki Diğer Bilgiler}

Şehir: İstanbul (Asya, Avr.), Kocaeli, Bursa, İzmir, Ankara, Eskişehir, Adana, Trabzon, Sivas

Firma Sektörü: Bankacılık, Finans

Personel sayısı: 35

İş Alanı: Genel Başvuru, Pazarlama, Satış

Tecrübe: Tecrübeli ya da tecrübesiz adaylar

Pozisyon Seviyesi: Yeni Başlayan

Pozisyon Tipi: Sürekli / Tam\&Yarı Zamanlı

İlgilenen adayların güncel özgeçmişlerini referans kodu ile birlikte basvuru@stratejik.com.tr adresine ya da 02164146521 numaralı faksa göndermeleri gerekmektedir. 